УДК 347.41

DOI https: / / doi.org/10.32837/yuv.v0i4.995

\title{
Г. Гриценко,
}

кандидат юридичних наук,

доцент кафедри цивільного, господарського і фінансового права

Полтавського юридичного інституту

Національного юридичного університету імені Ярослава Мудрого

\section{СУБСИДІАРНА ВІДПОВІДАЛЬНІСТЬ КРІЗЬ ПРИЗМУ МНОЖИННОСТІ ОСІБ У ЗОБОВ'ЯЗАННI}

Постановка проблеми. Кредитор завжди зацікавлений у додаткових гарантіях виконання зобов'язання. Однією із таких гарантій є наявність кількох боржників, до яких можна звернути вимоги. У науковій та учбовій літературі наявність кількох боржників у цивільно-правовому зобов'язанні пов'язують із явищем множинності осіб у зобов'язанні. Класичним прикладом зобов'язань 3 множинністю осіб $€$ солідарні та часткові зобов'язання. Часто до таких зобов'язань відносять і субсидіарну відповідальність. Проте такий підхід викликає спори, які мають не тільки теоретичний, а й практичний характер, оскільки відповідь на нього впливає на обсяг вимог, які можуть бути пред'явлені до субсидіарного боржника та умови звернення вимог до субсидіарних боржників.

Оцінка стану літератури, мета дослідження. Дослідженням окремих питань субсидіарної відповідальності присвячені праці Р. А. Майданика [1], С. В. Сарбаша [2], О. П. Прус [3], Д. В.Трута [4], I. С. Канзафарової [5] та багатьох інших вітчизняних та зарубіжних науковців. Проте, є потреба комплексного аналізу норм про субсидарну відповідальність 3 точки зору множинності осіб у зобов'язанні, а саме крізь призму основної мети норм про множинність осіб - поділити предмет зобов'язання між кількома кредиторами (боржниками) [6]. Чи можна твердити, що вона властива і субсидіарним зобов'язанням? Для відповіді потрібно проаналізувати аргументацію, яка наводиться як на користь, так і проти бачення субсидіарних зобов'язань, як зобов'язань з множинністю осіб.

Виклад матеріалу. Історично першими свої аргументи навели противники множинності. Їх критика зводиться до наступних тез. Як у договірних, так і у недоговірних зобов'язаннях, основний боржник i особа, на яку покладається субсидіарна відповідальність, $€$ учасниками окремих правовідносин (О. І. Масляєв). Відповідно, ця особа є третьою для зобов'язання, за невиконання якого вона відповідає (В. П. Маслов) «[Субсидіарні] зобов'язання виступають як засіб забезпечення виконання основних зобов'язань» [7, с.392]. Отже, вони є акцесорними. Крім цього, ще кілька аргументів проти множинності осіб наводить О. П. Прус: неспівпадіння предмету цих зобов'язань (субсидіарний боржник лише сплачує гроші); різний обсяг обов'язків основного і субсидіарного боржника (субсидіарний боржник сплачує те, що залишилось); неоднорівневий характер зобов'язань осиного і субсидіарного боржника; їх неодночасне виникнення; різні інтереси цих боржників (основний боржник має інтерес в еквіваленті, який надасть йому кредитор, а субсидіарний боржник такого еквіваленту вимагати не може, тому інтерес у нього в іншому); різні підстави для звернення кредитора з вимогою до боржника (для субсидіарного боржника це не тільки борг, а й його невиконання основним боржником) [3, с.70, 71]. На нашу думку, останні три аргументи навряд 


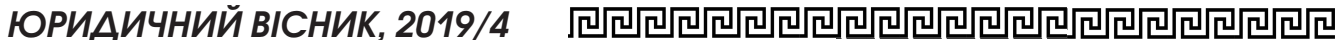

чи свідчать проти множинності осіб у зобов'язанні. Ті ж характеристики можна дати і солідарній відповідальності, хоча ніхто не піддає сумніву множинність осіб у цих відносинах. А от перші три аргументи заслуговують на ретельну увагу і тісно переплітаються із доводами прихильників множинності осіб.

Вчені, які вбачають множинність осіб у субсидіарних зобов'язаннях, як правило, не пояснюють свою позицію (Є. О. Суханов, О. В. Дзера, Ю.К. Толстой). Коли аргументація наводиться, вона, як правило, обмежується тим, що «відповідальність субсидіарного боржника не можна вивести за рамки зобов'язання, що пов'язує основного боржника і кредитора» [8, с.43, 164]. На цьому фоні вирізняється робота С. В. Сарбаша, доводи якого i будуть проаналізовані. Критикуючи O. I. Масляєва, він говорить, що не слід обмежуватись лише субсидіарною відповідальністю [2, с.23], бо можливий і субсидіарний борг.

Стосовно цього відмітимо таке. Переважна більшість вчених до обов'язку субсидіарного боржника відносять лише (Є. О. Суханов) або переважно [2, с.31] несення відповідальності. На підтвердження вказують в тому числі на розміщення ст.619 в положеннях ЦК - глава 51 (правові наслідки порушення зобов'язання, відповідальність за порушення зобов'язання). Хоча $€$ автори, які вважають, що на нього покладається обов'язок «виконати на користь кредитора частину або все зобов'язання у випадку невиконання боржником свого зобов'язання [7, с.348; 8, с.9, 50]. А вже за порушення i основного, і субсидіарного обов'язку, настає субсидіарна відповідальність (О. В. Дзера). Так само і в зарубіжному законодавстві: якщо згадується субсидіарний боржник, то в більшості країн він лише несе відповідальність. У той же час в законодавстві Республіки Казахстан і Таджикистан поряд із субсидіарною відповідальністю існують і субсидіарні зобов'язання. Нещодавно висловились, що положення статей про субсидіарну відповідальність насправді регулюють не тільки охоронні (недоговірні), а й регулятивні (договірні) правовідносини. Перші 3 них зумовлені винною поведінкою самого субсидіарного боржника, другі не пов'язані з будь-якими порушеннями з боку субсидіарного боржника $[3$, с.65, 66].

На нашу думку, це питання слід перевести у практичну площину. Тут $€$ кілька важливих моментів. По-перше, це сутність обов'язку субсидіарного боржника: виконання зобов'язання в натурі чи все-таки сплата грошей. Вітчизняні дослідники вважають, що формулювання ст.619 ЦК «дає підставу для висновку про те, що субсидіарна відповідальність означає можливість примушення субсидіарного боржника до виконання не тільки обов'язків основного боржника, що охоплюються категорією відповідальності, а й основних обов'язків, які складають зміст зобов'язання» [9, с.148]. На нашу думку, термін «вимога», який використав законодавець, справді не вносить ясність в те, чого можна вимагати. 3 одного боку, застосування санкцій за порушення зобов'язання не припиняє обов'язку виконати обов'язок в натурі (ст.622 ч.2 ЦК). 3 іншого - субсидіарний боржник з'являється в інтересах кредитора, але вже після того, як зобов'язання порушене. Тому в інтересах кредитора не втрачати час, з'ясовуючи, чи зможе субсидіарний боржник виконати зобов'язання в натурі. Справедливо надати йому право якнайшвидше отримати еквівалент - гроші. Отже, для всіх субсидіарних боржників варто встановити наступне правило: від них можна вимагати виконання зобов'язання основного боржника в натурі лише тоді, коли сторони домовились про це окремо.

По-друге, залежно від того, «зобов'язання» чи «відповідальність», буде різним обсяг обов'язку субсидіарного боржника. Якщо йдеться про відповідальність, то порушення субсидіарного боржника не буде тягнути його 
самостійну відповідальність. Тобто максимум, що він сплатить, - всю суму зобов'язань основного боржника, не більше. Неустойка нараховується тільки на борг за основним зобов'язанням. Інша річ, коли перед нами зобов'язання. У цьому разі на субсидіарного боржника цілком можна покласти окрему відповідальність за його власне порушення. Тобто його можна зобов'язати сплатити більше, ніж весь борг і відповідальність основного боржника. При цьому неустойка буде нараховуватись на всю суму зобов'язань основного боржника, адже для субсидіарного боржника все це - борг.

В українській літературі цей аспект обговорюється тільки при дослідженні поруки. Втім, порука - це специфічні відносини і поручитель далеко не єдиний субсидіарний боржник. В судовій практиці не вдалося знайти прикладів, коли позивачі вимагають більшу суму, ніж ту, яку винен основний боржник. Оскільки узагальнення української судової практики з питання субсидіарної відповідальності відсутні, звернемося до досвіду інших держав. У сусідній Білорусі, законодавство якої аналогічним чином регулює ці відносини, Пленум Вищого Господарського Суду прийняв постанову, спеціально присвячену субсидіарній відповідальності (Постанова Пленуму від 27.10.2006p. №11). У п.14 цієї постанови вказано, що відповідальність субсидіарного боржника може бути повною (рівною відповідальності основного боржника) або обмеженою (меншою, ніж у основного). При цьому наголошується, що вона «в будь-якому разі не може перевищувати об’єм відповідальності основного боржника». В російській літературі також на це неодноразово звертали увагу. Так, В. А. Бєлов, О. С. Комаров, М. М. Малеїна, Г. М. Шевченко вважають, що «субсидіарний боржник відповідає перед кредитором на тих же підставах, що й основний боржник, тому об'єм його відповідальності не може перевищувати об'єм відповідальності основного боржника».
Отже, з одного боку, більшість вчених кажуть, що субсидіарний боржник має сплачувати гроші, тобто ведуть мову про зобов'язання, відмінне від порушеного, а саме відповідальність. 3 іншого боку, коли мова заходить про розмір обов'язку субсидіарного боржника, вони стверджують, що він не може бути більшим за обов'язок основного боржника, бо вони відповідають на однакових підставах. Тоді цілком закономірно постає питання: якщо дві особи зобов'язані до одного й того ж, чи не свідчить це про множинність осіб, хоча б і в іншому зобов'язанні відповідальності? Мабуть, це найбільш вразливе місце в аргументації «проти» множинності осіб у субсидіарному зобов'язанні. В. А. Бєлов вказує, що обмеження $є$ прямим наслідком акцесорності цього зобов'язання. Все ж думається, що якщо, за словами в. А. Бєлова, «порушення основного і субсидіарного боржника - це два різні порушення; більше того, це порушення двох різних зобов'язань», тоді ніщо не повинно заважати нараховувати санкції за порушення субсидіарного боржника. Інша річ, що розмір таких санкцій має встановлюватись в законі або договорі (ст.549 ч.1 ЦК). Поки що законом це не передбачено. Але якщо сторони домовляться про це в договорі, таке положення не буде суперечити законодавству.

Власне кількість правовідносин, які виникають при субсидіарній відповідальності, - ие ключ до рішення, чи є множинність осіб у субсидіарному зобов'язанні. Противники множинності завжди посилаються на наявність кількох зобов'язань. Прихильники, прямо цього не висловлюючи, все-таки говорять про єдине зобов'язання. Зокрема, коли субсидіарне зобов'язання відносять до виду часткових (В. П. Маслов), або коли говорять, що субсидіарна відповідальність має місце тоді, коли в зобов'язанні беруть участь два боржники, один з яких основний, а інший - додатковий (M. М. Сибільов). Досить несподівану 


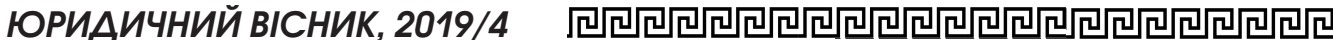

позицію висловила I. С. Тімуш, яка переконана, що субсидіарні зобов'язання можуть складатися, як із кількох правовідносин (порука), так і з єдиного зобов'язання (відповідальність батьків за шкоду, завдану неповнолітньою особою) $[1$, с.751].

На нашу думку, будь-яка субсидіарна відповідальність означае наявність двох різних зобов'язань, окремих правовідносин. Ми виходимо з того, що обов'язок субсидіарного боржника не співпадає за змістом із обов'язком основного боржника. Крім цього, він може відрізнятися й за обсягом і не тільки у менший бік. При відповідній умові договору можна застосовувати санкції за порушення зобов'язання субсидіарним боржником. Ці обставини свідчать про те, що субсидіарний боржник, незважаючи на назву, є стороною іншого зобов'язання. Перебуваючи в різних зобов'язаннях, основний $i$ субсидіарний боржник не можуть утворити множинність осіб. У них немає спільного предмету, який потрібно ділити, а це основне призначення (мета) множинності осіб у зобов'язанні.

На підтвердження різних правовідносин можна навести й інші аргументи. Зокрема, вже згадана акцесорність зобов'язання додаткового боржника. Існування одного правовідношення поставлено в залежність від умови порушення іншого зобов'язання. Внаслідок цього боржники займають неоднорівневе становище. Слід відмітити, що й становище солідарних боржників може різнитися: різні строки виконання чи наявність умови. Тим не менш, існування їх обов'язків поставлено в залежність не від зобов'язань інших боржників, а від якихось зовнішніх обставин. Їх настання впливає на той конкретний обов'язок, до якого строк чи умова прив'язані, а не на зобов'язання інших боржників. У субсидіарному зобов'язанні, навпаки, будь-які маніпуляціі з обов'язком основного боржника впливають на обов'язок додаткового боржника. А от припинення, зміна остан- нього ніяк не вплинуть на основне зобов'язання. Основний боржник може домовитись із кредитором збільшити, зменшити борг, взагалі припинити зобов'язання і все це без згоди субсидіарного боржника. Якби ці боржники були учасниками одного зобов'язання, основний боржник не зміг би так вільно поводитися із спільним предметом зобов'язання.

Стосовно прикладу відповідальності батьків за неповнолітніх, то він вже ставав предметом спору в літературі. Так, O. I. Масляєв вважає, що при завданні шкоди неповнолітньою особою правовідношення виникає «або між заподіювачем шкоди і потерпілим, або (коли у заподіювача відсутні доходи і майно, достатні для відшкодування шкоди) батьків (усиновлювачів, піклувальника) і потерпілої особи» [10, с.366]. С. В. Сарбаш зауважує йому, що «якщо неповнолітня особа не була стороною зобов'язання, коли субсидіарна відповідальність була покладена на вказаних третіх осіб, то на якій підставі вона стала боржником після появи доходів і майна? Остання обставина підтверджує наявність тут множинності» [2, с.24, 25]. Тобто перший робить акцент на двох зобов'язаннях, а другий - на тому, що зобов'язання одне, але основний боржник не вибуває із нього. Те, що він зараз не може його виконати, ще не значить, що згодом до нього не можна пред’явити вимогу. В принципі таке враження складається при прочитанні ст.619 ЦК. В ЦК 2003 року регулювання субсидіарної відповідальності зазнало суттєвих змін: тепер до субсидіарного боржника можна пред'явити вимогу навіть тоді, коли основний боржник в розумний строк просто не відповів на вимогу кредитора (ст.619 ч.2 ЦК). Це нововведення отримало позитивні відгуки практиків. Втім, деякі вчені поставились до них з осторогою. Так, I. С. Канзафарова вважає, що у теперішньому вигляді конструкція ст.619 ЦК - «це ніщо інше, як звичайна (основна) цивільно-правова відповідальність 3 альтернативністю боржників» [5, с.140]. 
Висновки і перспективи подальших досліджень. На нашу думку, у всіх випадках субсидіарної відповідальності основний боржник дійсно не вибуває із зобов'язання, але із свого зобов'язання. Кредитор, маючи права в обох правовідносинах, реалізує ї на свій вибір після порушення основного зобов'язання і пред'явлення вимог основному боржнику. Ця схема «або-або» властива окремим правовідносинам. У зобов'язаннях з множинністю осіб, навпаки, кредитор може скористатися своїм правом за схемою «i-i», тобто одночасно задiяти всіх боржників. Перспективами подальших досліджень має бути аналіз правового становища субсидіарного боржника не тільки з точки зору його матеріально-правого, а й з точки зору процесуального статусу.

У статmі аналізуеться субсидіарна відповідальність з точки зору наявності множинності осіб (боржників). Викладені основні аргументи науковиів, які є прихильниками та противниками множинності осіб у випадку субсидіарної відповідальності. Автор робить висновок, щзо субсидіарний та основний боржник не утворюють множинності осіб, оскільки є учасниками різних зобов'язань, одне з яких є акцесорним. У моделі «основний - субсидіарний боржник» кожен із боржників має свій власний предмет зобов'язання, тобто не виконується основне призначення норм про множинність осіб - необхідність поділу предмет у зобов'язання між кількома особами. Субсидіарний боржник може нести окрему відповідальність за порушення свого зобов'язання, яка є додатковою до відповідальності основного боржника. Субсидіарним є виключно боржник, тоді як в інших зобов'язаннях з множинністю осіб кілька осіб можуть бути як на боці кредитора, так i на боці боржника. Автор доходить висновку, щз у всіх випадках субсидіарної відповідальності звернення до субсидіарного боржника не означає припинення обов'язку основного боржника. Кредитор р має право звертатися з вимогою до субсидіарного боржника навіть у тому випадку, якщзо основний боржник просто ігнорує вимогу кредитора. Тобто основний боржник не вибуває із зобов'язання, проте із свого власного зобов'язання. Кредитор, маючи права в обох правовідносинах, реалізує їх на свій вибір після порушення основного зобов'язання $i$ пред’явлення вимог основному боржнику. Ця схема «або-або» властива окремим правовідносинам. У зобов'язаннях з множинністю осіб, навпаки, кредитор може скористатися своїм правом за схемою «i-i», тобто одночасно задіяти всіх боржників.

Ключові слова: субсидіарна відповідальність, субсидіарний боржник, зобов'язання 3 множинністю осіб

Hrytsenko H. SUBSIDIARY RESPONSIBILITY THROUGH A VIEW OF PLURALITY OF PERSONS IN CIVIL OBLIGATION

The article analyzes the subsidiary liability in terms of a plurality of persons (debtors) in civil-law obligation. The main arguments of scholars who are supporters and opponents of a plurality of persons in the case of subsidiary liability are outlined. The author concludes that the subsidiary and the principal debtor do not form a plurality of persons, as they are participants in two separate civil-law obligations, one of which is an accessory one. In the "principal subsidiary debtor" model, each debtor has his or her own object of civil-law obligation, that is, the basic purpose of the rules concerning a plurality of persons in civil-law obligation (- the need to divide the object into obligations between several persons) is not fulfilled. The subsidiary debtor may be held individually liable for breach of its obligation, which is additional to the liability of the 


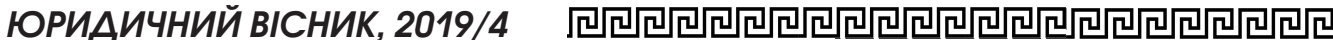

principal debtor. Subsidiary is solely the debtor, while in other obligations with a plurality of persons, several persons may be on both the creditor's side and the debtor's side. The author concludes that in all cases of subsidiary liability, submitting a claim to a subsidiary debtor does not mean the termination of the principal debtor's obligation. The creditor has the right to submit his or her claim to a subsidiary debtor even if the principal debtor simply ignores the creditor's claim. That is, the principal debtor does not withdraw from the obligation, but it means that he or she remains in his or her own obligation. The creditor, having the rights in both legal relationships, realizes them at his choice after breach of the principal obligation and making claims against the principal debtor. This scheme "or-or" is peculiar to two separate relationships. In liabilities with a plurality of persons, on the contrary, the creditor may exercise his right under the "and-and" scheme, that is, simultaneously involve all debtors.

Key words: subsidiary liability, subsidiary debtor, plurality of persons

\section{Література}

1. Аномалії в цивільному праві України: Навч.-практ. посібник / Biдn. ред. Р.А. Майданик. - К.: Юстиніан, 2007. - 912 c.

2. Сарбаш С. В. Обязательства с множественностью лии и особенности их исполнения / C. В. Сарбаш. - М. : Стаmym, 2004. $-112 \mathrm{c}$

3. Прус Е. П. Проблемы правового регулирования субсидиарных обязательств учредителей (участников) юридического лица: дис. ... канд. юрид. наук: 12.00.03/ Прус Елена Павловна. - М., 2006. - 216 с.

4. Трут Д. В. Субсидіарні зобов'язання як різновид изивільно-правових зобов' язань з множинністю осіб / Д. В. Трут / / Універ. наук. записки. - 2012. - № 4. - С. 186-192

5. Канзафарова I.C. Теорія цивільно-правової відповідальності / Biдn. ред. Я. М. Шевченко. - Одеса: "Acmponрінт», 2006.- 264c.

6. Гриценко Г. Г. Види зобов'язань з множинністю осіб за цивільним законодавством іноземних країн [Електронний ресурс / / Г. Г. Гриценко / / Форум права.: електрон. наук. фах. Вид. 2016. - №4. - C. 77-83. - Режuм docmyny: http: / / nbuv.gov.ua/j-pdf/FP_index. htm_2016_4_15.pdf

7. Советское гражданское право: Учебник. В 2 ч. / Под ред. В.Ф. Маслова и А.А. Пушкина. - 2-е изд., перер. и доп. - K.: Вища школа, 1983. - 4. 1. - 462 с.

8. Храпунова Е.А.. Субсидиарная ответственность в гражданском праве. Дис. ... канд. юрид. наук: 12.00 .03 / Храпунова Екатерина Александровна - Ростовна-Дону, 2001. - $185 \mathrm{c}$.

9. Науково-практичний коментар до иивільного законодавства України: [В 4 m.] / А. Г. Ярема, В. Я. Карабань, В. В. Кривенко, В. Г. Ротань. - Т. 2. - К.: A.C.K.; Севастополь: Iн-m юрид. дослідж., 2004. - 864 C.

10.Гражданское право: /учеб. для вузов по спеи. "Юриспрудениия»: часть первая / H. Н. Агафонова, C. В. Артеменков, В. В. Безбах и др.l ; отв. ред. В. П. Мозолин, А. И. Масляев ; Моск. гос. юрид. акад. - М. : Юристъ, 2007. - 719 с. 